\title{
Effect of Long Non-Coding RNA AOC4P on Gastrointestinal Stromal Tumor Cells [Retraction]
}

$\mathrm{Hu}$ JC, Wang Q, Jiang LX, et al. Onco Targets Ther. 2018;11:6259-6269.

The Editor and Publisher of OncoTargets and Therapy wish to retract the published article. Concerns were raised regarding the alleged duplication of images in Figure 3 and Figure 5. The authors responded to our queries but were unable to provide an explanation for the alleged image duplication and were unable to verify their original data and have therefore agreed to retract the article.

Our decision-making was informed by our policy on publishing ethics and integrity and the COPE guidelines on retraction.

The retracted article will remain online to maintain the scholarly record, but it will be digitally watermarked on each page as "Retracted".

\section{Publish your work in this journal}

OncoTargets and Therapy is an international, peer-reviewed, open access journal focusing on the pathological basis of all cancers, potential targets for therapy and treatment protocols employed to improve the management of cancer patients. The journal also focuses on the impact of management programs and new therapeutic agents and protocols on patient perspectives such as quality of life adherence and satisfaction. The manuscript management system is completely online and includes a very quick and fair peer-review system, which is all easy to use. Visit http://www.dovepress.com/ testimonials.php to read real quotes from published authors. 